\title{
HUKUM MENSHALATKAN JENAZAH PENDUKUNG PENISTA AGAMA DAN PEMILIH NON MUSLIM MENJADI PEMIMPIN
}

\author{
Ronny Mahmuddin
}

Sekolah Tinggi Ilmu Islam dan Bahasa Arab (STIBA) Makassar,

Jl. Inspeksi PAM Manggala-Antang Makassar

E-Mail: ronnymahmuddin@gmail.com

\section{Keywords :}

die, blasphemy, unbeliever

\section{ABSTRACT}

\begin{abstract}
Refusing to perform prayer for the dead who supported blasphemy and voted for an infidel to be a ruler for a Muslim society implies the accusation of someone to be an unbeliever.Labelling a Muslim to be an unbeliever is equal to accusing him to commit apostasy, which subsequently means that it is permissable either to take his life or to shed his blood, even to divorce him from his wife. When he dies, his body will not be: performed for ablution, wrapped by shroud, held for prayer, burried in Muslim burial area, and his wealth is not allowed to be inherited by any of his inheritees. Moreover, he is to fall into the Hellfire eternally for dying upon infidel state. This paper was going to scrutinize the issue of "Is it permissable to perform prayer for the dead who supported blasphemy and voted for a non-Muslim to be a ruler for a Muslim society?" Prior to further elaboration, this paper was going to pinpoint 3 significant items: are those who say something and commit an action of an infidel; worship another God beside Allah; or practice deviant creed automatically labelled to be an infidel? What are the conditions of someone to be included or not as an infidel? And is it permissable to vote for a non-Muslim ruler e.g, governor for a Muslim society? This paper employed literature study.
\end{abstract}




\section{PENDAHULUAN}

Melihat besarnya urgensi judul ini karena tidak mensholatkan jenazah pendukung penista agama dan pemilih orang kafir menjadi pemimpin kaum muslimin berarti ini merupakan vonis kafir (keluar dari Islam) yang dijatuhkan kepada orang muslim yang mendukung penista agama dan pemilih orang kafir menjadi pemimpin. Permasalahan ini sangat penting untuk dibahas dan dikaji secara mendalam.

Memvonis kafir seorang Muslim adalah berarti memvonisnya keluar dari Islam, darah dan hartanya halal, dan pernikahannya dengan istrinya harus dipisahkan. Jika ia meninggal maka tidak dimandikan, tidak dikafani, tidak disholatkan dan tidak dikuburkan di pekuburan kaum muslimin, dan hartanya tidak diwariskan kepada ahli warisnya jika ia meninggal dunia, dan bahkan ia kekal di neraka jahannam jika ia meninggal dunia di atas kekafirannya. Dan kita harus melihat besarnya bahaya mengkafirkan orang muslim yang belum terbukti kekafirannya, sebagaimana sabda Nabi shollallahu 'alahi wa sallam:

$$
\begin{aligned}
& \text { قال البي صلى الله عليه وسلم: ((لا يرمي رجل رجلا }
\end{aligned}
$$

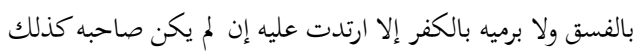

$$
\begin{aligned}
& \text { ()) متفق عليه }
\end{aligned}
$$

Artinya:

"Tidaklah seseorang menuduh orang lain dengan tuduhan fasik dan tuduban kafir, melainkan perkataannya itu kembali kepadanya jika tidak benar apa yang ia tudubkan". (HR. Bukhari no. 6045 dan Muslim no. 61).

Bolehkah kita langsung
menghukum kafir seseorang tatkala ia terjatuh dalam kekafiran? Dan bolehkah kita mengatakan bahwa tidak boleh mensholatkan jenazah seorang muslim yang melakukan kekufuran seperti mengucapkan kata-kata kafir, melakukan perbuatan kafir, memilih orang kafir menjadi pemimpin?

Jadi sebelum kita memutuskan bahwa tidak boleh mensholatkan orang Islam yang mendukung penista agama dan pemilih orang kafir menjadi pemimpin bagi ummat Islam, maka kita harus sepakati terlebih dahulu apakah setiap orang Islam yang mendukung penista agama atau setiap orang Islam yang memilih orang kafir menjadi pemimpin bagi ummat Islam divonis kafir (keluar dari Islam)? Jika jawabannya "Iya", maka kita tidak boleh mensholatkan setiap muslim yang mendukung penista agama atau yang memilih orang kafir menjadi pemimpin bagi ummat Islam, karena orang muslim tersebut telah kafir dan keluar dari Islam. Namun jika jawabannya "Tidak Kafir", maka kita berkewajiban untuk mensholatkan mereka, karena mensholatkan jenazah orang Islam adalah salah satu hak dari hak-hak muslim yang harus kita penuhi.

Namun harus ditetapkan terlebih dahulu bahwa apakah memilih pemimpin kafir termasuk perbuatan kafir yang menyebabkan pelakunya keluar dari Islam atau tidak kafir hanya termasuk perbuatan dosa besar yang tidak menyebabkan pelakunya keluar dari Islam atau dibolehkan dalam agama Islam, karena ada dari kaum muslimin yang membolehkan memilih non muslim menjadi pemimpin seperti gubernur? Ini harus dijelaskan agar kita mudah menetapkan sebuah hukum bagi pemilih non muslim menjadi 
pemimpin atas umat Islam khususnya di negeri ini.

Berdasarkan itu semua, maka kami pandang perlu untuk menulis sebuah makalah yang membahas masalah ini.

1. Apakah setiap orang yang mengatakan perkataan kafir atau melakukan perbuatan kafir, syirik atau nifaq aqidah serta merta divonis kafir (keluar dari Islam)?

2. Apa syarat-syarat seorang muslim dapat divonis kafir dan apa hal-hal yang menghalanginya sehingga tidak bisa divonis kafir?

3. Bolehkah memilih non muslim menjadi pemimpin bagi kaum muslimin seperti gubernur?

4. Bolehkah disholatkan jenazah orang yang mendukung penista agama dan pemilih non muslim menjadi pemimpin sebelum ditegakkan hujjah atas pelakunya?

\section{PEMBAHASAN}

A. Memvonis Kafir Secara Mutlak dan Memvonis Kafir Individu Tertentu

Menghukumi kafir suatu perkataan atau perbuatan, maka ini ada kaitannya dengan penjelasan hukum syar'i secara mutlak. Adapun menghukumi seseorang kafir apabila dia meyakini atau berkata atau melakukan perbuatan kufur yang menyebabkan pelakunya keluar dari Islam, seperti mengingkari perkara agama yang mesti diketahui oleh ummat Islam, dan seperti mencaci maki Allah atau

1Prof. DR. Abdullah Bin Abdul Azīz AlJibrīn, Dawābiț Takfïr Mu'ayyan, (Riyāḍ: Fahrasat Maktabah Malik Fahad, 1425), h. 3. mencaci maki Islam, sebelum menetapkan bahwa orang tersebut kafir, maka harus terlebih dahulu tabayyun (memastikan) tentang kondisi orang tersebut, yaitu dengan mengetahui apakah sudah terpenuhi semua syarat-syarat pada orang tersebut sehingga dapat dihukumi kafir atau syarat-syarat tersebut belum terpenuhi? Dan apakah tidak ada semua penghalang-penghalang yang ada padanya?1

Syaikhul Islam Ibnu Taimiyyah rabimabullah berkata: "Sesungguhnya pengkafiran (menghukumi kafir) memiliki syarat-syarat dan penghalang-penghalang yang terkadang tidak berlaku pada pengkafiran (menghukum kafir) seseorang. Dan pengkafiran secara mutlak (umum) tidak serta merta harus berlaku pada pengkafiran (menghukumi kafir) seseorang, kecuali jika terpenuhi syaratsyaratnya dan tidak ada penghalangpenghalangnya. Yang menjelaskan tentang ini bahwa Imam Ahmad dan seluruh para imam (ulama) menyebutkan pengkafiran secara umum, yaitu siapa yang berkata atau berbuat demikian (perkataan/perbuatan kafir), maka ia telah kafir, namun mereka tidak mengkafirkan secara individu (perorangan) yang mengatakan kata-kata kufur.

Imam Ahmad bin Hanbal rabimabullah hidup di sebuah negara yang pada saat itu dikuasi oleh kaum Jahmiyah. Mereka mengajak Imam Ahmad untuk mengatakan bahwa al-Qur'an adalah makhluq, dan menafikan sifat-sifat Allah. Mereka menyiksa para ulama dan kaum muslimin yang tidak mengikuti aqidah mereka dengan siksaan berupa pukulan, 
penjara, pembunuhan, diasingkan, tidak diberi upah (tunjangan), ditolak kesaksiannya serta tidak dibebaskan dari tangan musuh-musuh. Dimana pada saat itu kebanyakan dari pemerintah dan para hakim dan selain mereka menganut paham Jahmiyah. Mereka mengkafirkan siapa saja yang tidak berpaham Jahmiyah yang tidak menafikan sifat-sifat Allah, dan yang tidak mengatakan al- Qur'an adalah makhluq. Namun Imam Ahmad justru mendoakan khalifah dan selainnya yang menyiksa dan memenjarakan beliau dan beliau memohonkan ampun atas mereka dan memaafkan atas kezholiman mereka seperti mengajaknya untuk mengatakan perkataan kufur. Seandainya mereka murtad dari Islam, maka tidak boleh beliau memohonkan ampun untuk mereka.

\section{B. Syarat-Syarat Seorang Muslim Dapat Divonis Kafir dan Hal-Hal Yang Menghalanginya.}

Pada pembahasan ini, kami akan memaparkan syarat-syarat yang harus terpenuhi sehingga seorang muslim bisa divonis kafir dan hal-hal apa yang menghalangi seorang muslim untuk tidak bisa divonis kafir, sebagai berikut:

\section{a. Syarat-Syarat Seorang Muslim Dapat Divonis Kafir: \\ Para ulama menyenutkan} syarat-syarat seseorang dapat divonis kafir tatkala ia melakukan perbuatan kafir atau mengucapkan kata-kata kafir, yaitu sebagai berikut:

${ }^{2}$ Muhammad bin Sālih Al-Ușaimīn, Majmu' Fatāwa, Vol. II (Riyāḍ: Dār al Wațan, 1413), h. 125-126.

${ }^{3}$ Muhammad bin Sālih Al-Ușaimīn, Majmu' Fatāwa, Vol. II, h. 126.
1. Adanya

Ilmu/Pengetahuan.

Maksudnya adalah orang tersebut mengetahui bahwa perbuatan kafir tersebut adalah haram ${ }^{2}$. Namun jika dia tidak mengetahui maka ia tidak divonis kafir sebagaimana firman Allah dalam surah al-Nisaa: 115:

"Dan Barangsiapa yang menentang Rasul sesudah jelas kebenaran baginya, dan mengikuti jalan yang bukan jalan orangorang mukmin, Kami biarkan ia leluasa terhadap kesesatan yang telah dikuasainya itu dan Kami masukean ia ke dalam Jahannam, dan Jahannam itu seburuk-buruk. tempat kembali.

Akan tetapi jika ia meremehkan dengan tidak mau belajar dan mencari kebenaran maka ia tidak dimaafkan seperti takala sampai kepadanya bahwa amalannya tersebut adalah amalan kafir namun ia tidak memastikan dan tidak mencari kebenarannya maka pada saat itu ia tidak dimaafkan. ${ }^{3}$

\section{Unsur Kesengajaan.}

Maksudnya adalah orang tersebut melakukannya dengan sengaja. ${ }^{4}$ Namun jika ia lakukan tanpa sengaja (bukan keinginannya) melakukan perbuatan kafir, maka ia tidak divonis kafir seperti pikirannya tertutup sehingga tidak mengetahui apa yang ia lakukan disebabkan karena sangat gembira atau semisalnya seperti perkataan pemilik unta yang tersesat di padang pasir kemudiann berbaring di bawah pohon seraya menunggu ajalnya, namun tiba-tiba tali kekang untanya terikat di pohon, maka dia segera mengambilnya seraya berkata: "Ya Allah, Engkau adalab hambaku dan Aku adalah tuban-Mu". (HR. al-Bukhari

\footnotetext{
${ }^{4}$ Muhammmad bin Sālih Al-Ușaimīn, Majmu' Fatāwa. h. 125-126.

5Imam Ahmad bin Ali Ibn Hajar AlAsqalanī, Fathul Bārī Syarhu Śahīh al-Bukhārī, Vol. XI, (Kairo: Maktabah al-Ṡofa, 1424), h. 118.
} 
no. 6309 dan Muslim no. 2747). Dia salah mengucapkan kata-kata karena sangat gembiranya. Namun jika ia melakukan perbuatan kafir dengan bercanda, maka ia divonis kafir karena ia sengaja/bermaksud untuk melakukan amalan tersebut, sebagaimana yang ditetapkan oleh para ulama ${ }^{6}$

\section{Tanpa Paksaan/ Keinginan Sendiri.}

Maksudnya adalah orang tersebut melakukannya dengan keinginannya sendiri, yaitu tidak dipaksa untuk mengucapkan atau melakukan perbuatan kafir, sebagaimana firman Allah dalam QS. al-Nahl/16:106, dan perkara ini sudah disepakati oleh para ulama. ${ }^{7}$

Barangsiapa yang kafir kepada Allah sesudah Dia beriman (dia mendapat kemurkaan Allab), kecuali orang yang dipaksa kafir Padahal hatinya tetap tenang dalam beriman (dia tidak berdosa), akan tetapi orang yang melapangkan dadanya untuk kekafiran, Maka kemurkaan Allah menimpanya dan baginya azab yang besar.

\section{b. Hal-Hal Yang Menghalangi Seorang Muslim Tidak Dapat Divonis Kafir:}

\section{Ketidaktahuan.}

Sebagian para ulama telah menyebutkan diantara dalil penghalang ini (ketidaktahuan) adalah kisah seorang lakilaki yang tidak melakukan sedikit pun amalan kebaikan, lalu ia menyuruh anakanaknya ketika ia mati untuk membakarnya, kemudian menyuruh mereka untuk membuang abunya ke laut pada saat angin yang sangat kencang. Ia

'Imam Ahmad bin Ali Ibn Hajar AlAsqalanī, Fathul Bārī Syarhu Sahīh al-Bukhārī, h. 126.

7 Prof. DR. Abdullah Bin Abdul Aziz AlJibrin, Dawābiț Takfir Mu'ayyan, h. 10. berkata: "Demi Allah sungguh jika Allah menguasai aku, sungguh Dia pasti menyiksa aku dengan siksaan yang belum pernah Dia siksa atas seorang pun”. Maka, Allah pun mengampunkan dosanya. (HR. Bukhari no: 3478 dan 3481 dan Muslim no: 2756-2757).

\section{Adanya Syubhat.}

Sebagian para ulama menyebutkan bahwa disebabkan penghalang ini (takwil), maka para sahabat nabi Saw tidak mengkafirkan kaum Khawarij yang memberontak dan memerangi kaum muslimim. Mereka memerangi Khalifah Ali Bin Abi Tholib, mereka menghalalkan darah beliau hingga mereka dapat membunuh beliau. Kaum Khowarij menghalalkan darah seluruh kaum muslimin yang menyelisihi mereka bahkan sebagian perkara/perbuatan yang mereka kerjakan termasuk perkara yang menyebakan pelakunya keluar dari Islam. $^{8}$

Syaikhul Islam Ibnu Taimiyyah berkata: "Para sahabat nabi tidak mengkafirkan kaum Khawarij padahal mereka mengkafirkan Utsman bin Affan dan Ali bin Abi Tholib dan kaum muslimin yang setia kepada keduanya. Mereka menghalalkan darah kaum muslimin yang menyelisihi mereka".? Kaum Khawarij tidak dikafirkan karena pada diri mereka ada syubhat takwil terhadap ayat-ayat Allah dan selainnya. Ini dapat kita saksikan ketika Abdullah bin Abbas menegakkan hujjah atas mereka dengan melakukan diaolog dengan mereka di sebuah desa di

8 Prof. DR. Abdullah Bin Abdul Aziz AlJibrin, Dawabiț Takfir Mu'ayyan, h. 22-23.

9 Ibnu Taimiyyah, Syaikhul Islam Ahmad, Majmu' Fatāwa, Vol. III (Riyāḍ: Mujamma' Malik Fahad, 1416), h. 282-283. 
Harurah di Kufah. ${ }^{10}$ Diantara bentuk syubhat lainnya adalah syubhat kepentingan pribadi. Nabi Saw tidak mengkafirkan Hathib Bin Abi Balta'ah radbiallabu 'anbu karena adanya syubhat (penghalang) yang ada padanya. Perbuatan Hathib adalah perbuatan yang diharamkan yakni menolong orang kafir dari kaum muslimin atau membuka rahasia kaum muslimin yang akan melakukan penyerangan terhadap kaum kafir Mekkah. Syubhatnya adalah Hathib ingin orang-orang kafir Quraisy di kota Mekkah dapat mempersiapkan diri untuk berperang. Disebabkannya ada syubhat ini, maka nabi Saw tidak mengkafirkan atau menghukum Hathib. Hanya satu syubhat yang ada pada diri Hathib, yaitu kepentingan pribadi $^{11}$.

\section{Hukum Memilih Non Muslim Menjadi Pemimpin.}

- Ibnul Qayyim dalam kitabnya Abkam Ablu adz-Drimmah mengatakan bahwa Allah telah menetapkan bahwa siapa yang loyalitas atau menjadikan non muslim sebagai wali/pelindung, maka ia termasuk dari golongan mereka. Tidak sempurna keimanan kecuali berlepas diri dari mereka. Kecintaan itu menafikan kebencian, maka keduanya tidak akan pernah bersatu selama-lamanya. Kecintaan adalah pemuliaan maka tidak akan bisa bersatu dengan penghinaan terhadap kekufuran, dan kecintaan itu adalah hubungan, maka tidak akan pernah bersatu dengan kebencian terhadap orang kafir. ${ }^{12}$

${ }^{10}$ Salim bin 'led Al-Hilāliī, Limāża Ikhtartu al-Manhaj al-Salafí? (Cet. 1. t.t., Markaz Dirāsat al-Manhajiyyah al-Salafiyyah, 1420), h. 101-104.

${ }^{11}$ Prof. DR. Abdullah Bin Abdul Aziz al-Jibri al-Jibrīn, Dawābiț Takfir Mu'ayyan, h. 53, dikutip dari risalah Mualāt al-Kuffar Bii'anatihim 'ala alMuslimin, Syaikh Abdullah bin Abdul Aziz al-Jibrin.
- Komite Tetap Pengkajian dan Fatwa Saudi Arabia mengatakan bahwa tidak boleh memberikan suara kepada orang kafir dalam pemilihan umum meskipun orang kafir tersebut adalah orang yang baik karena itu mengangkat kedudukan orang kafir dan menguatkan urusan mereka serta menjadi jalan bagi mereka untuk berkuasa atas kaum muslimin, dalilnya dalam surah al-Nisaa: $141 .^{13}$

- Juga dalil tentang ketidak bolehan non muslim menjadi pemimpin adalah surah al-Maidah: 51 . Pada ayat tersebut menyebutkan bahwa ummat islam dilarang mengangkat orang yahudi dan nasrani menjadi wali bagi kaum muslimin, yang bisa berarti teman setia, penolong, pelindung atau pemimpin.

- Imam Ahmad meriwayatkan dari Abu Musa al-Asy'ariy berkata: Saya berkata kepada Umar: "Saya mempunyai seorang juru tulis beragama nasrani. Maka Umar marah, dengan mengatakan: "Tidakkah engkau mendengar firman Allah "Wabai orangorang yang beriman, janganlab kaian menjadikan kaum yahudi dan nasrani sebagai wali, sebagian mereka menjadi wali bagi yang lainnya”. (Qs. Al-Maidah: 51). Kenapa kamu tidak menunjuk orang muslim sebagai juru tulismu. Abu Musa berkata: "Wahai Amirul Mukminin, saya hanya butuh tulisannya dan baginya agamanya". Umar menjawab: "Saya tidak akan menghormati mereka karena Allah menghinakan mereka, dan saya tidak akan memuliakan mereka

\footnotetext{
12Syamsuddin Muhammad bin Abī Abū Bakar bin al-Qayyim Al-Jauziyah, Ahkām Ahli alŻimmah (Dammām: Ramādī Li al-Nasyr, 1418), h. 499.

${ }^{13}$ Lajnah Dāimah, Fatāwa al-Lajnah alDāimah Li al-Buhūs al-Ilmiyyah wal Iftā (Riyāọ: Muassasah al-Amirah al-Anud Binti Abdul Aziz Alū Saūd al-Khairiyyah: 1431), h. 546.
} 
Website: https://journal.stiba.ac.id

ISSN : 2685-7537 (online) 2338-5251 (Printed)

karena Allah telah merendahkan mereka dan saya tidak akan menjadikan mereka sebagai orang dekat karena Allah telah menjauhkan mereka ${ }^{14}$. Begitu juga larangannya terdapat pada surah al-Taubah: 23, al-Mujadilah: 22, al-Mumtahanah: 1 dan al-Maidah: 55, begitu pula surah al-Fath: 29, dan alHujurat: 10.

\section{Hukum Mensholatkan} Jenazah Pendukung Penista Agama dan Pemilih Non Muslim Menjadi Pemimpin

Pada pembahasa di poin $\mathrm{C}$ telah jelas bahwa tidak boleh (haram) memilih orang non muslim menjadi pemimpin. Namun apakah keharamannya ini menyebabkan pelakukan bisa kafir atau keluar dari Islam? Syaikh Sholih bin Fauzan al-Fauzan mengatakan bahwa membantu orang-orang kafir terhadap kaum muslimin terbagi menjadi lima keadaan, diantaranya adalah mencintai orang-orang kafir dan kasih sayang kepada mereka tanpa menolong mereka untuk memerangi kaum muslimin, maka ini dilarang oleh Allah Ta'ala. Allah Ta'ala berfirman dalam surah al-Mujadilah: 22: ${ }^{15}$

Dalil tentang kisah Hathib bin Abi Balta'ah dimana nabi meminta tabayyun kepada Hathib yang melakukan perbuatan membantu orang kafir. Hathib melakukan perbuatan demikian karena ada kepentingan pribadinya yakni untuk menyelamatkan keluarganya dari serangan kaum muslimin. Juga kisah tentang 'Ammar bin Yassir radbiallahu 'anhu tatkala ia mengucapkan kata-kata kufur, nabi tidak

${ }^{14}$ Sholih bin Fauzan Al--Fauzan, al-Wala wal Bara Fi al-Islam (Riyadh: Dar al-Wathan, 1412), h. 11.

${ }^{15}$ Prof. DR. Abdullah Bin Abdul Aziz AlJibrin, Dhowabith Takfir Mu'ayyan., h. 48, dikutip menghukum dia sebagai orang kafir akan tetapi meminta tabayyun terlebih dahulu kepada Ammar atas perbuatannya. Ammar melakukan demikian karena dia dipaksa oleh orang kafir. Adapun menista/mencela agama, maka itu salah satu pembatal dari keislaman seseorang atau perbuatan/perkataan kufur yang menyebabkan seseorang keluar dari agama Islam. Hal ini disebutkan oleh syaikh Muhammad bin Abdul Wahhab tentang sepuluh pembatal-pembatal keislaman seseorang, diantaranya adalah mencela atau membenci apa yang dibawa oleh rasulullah Saw, yakni agama Islam meskipun dia mengamalkan ajaran Islam. Dalilnya adalah surah al-Taubah ayat 65-66: ${ }^{16}$

Harus dipastikan apakah mereka mendukung penista agama kerena mereka setuju dengan penistaan agama tersebut atau tidak? Jadi harus dipastikan apa motif dukungan tersebut. Boleh jadi juga bahwa ada syubhat lain, yaitu tentang tafsiran surah al-Maidah ayat 51 tentang makna alwali, yang mana ada ulama di negeri ini yang menafsirkan al-wali bukan pemimpin akan tetapi teman setia. Kemungkinan masih ada syubhat-syubat lainnya. Jadi banyak syubhat yang harus dihilangkan sebelum dihatuhkan vonis atas mereka. Dan yang berhak menjatuhkan vonis kafir pun atas seseorang (individu) adalah para ulama bukan setiap orang, apatah lagi orang awam yang tdiak punya ilmu atau penuntut ilmu pemula atau yang masihh mempunyai ilmu yang dangkal. Allahu a'alam.

Dengan demikian bahwa pendukung penista agama dan pemilih

dari Risalah Muzhoharah al-Khuffar 'Ala alMuslimin, Syaikh Sholih al-Fauzan.

${ }^{16}$ Sholih bin Fauzan Al-Fauzan, Silsilah Syarhu al-Rasaail (Riyadh: Dar al-Ma'tsur, 1436), h. 143. 
orang kafir menjadi pemimpin boleh disholatkan jenazahnya selama belum ditegakkan hujjah atas orang per orang. Namun jika telah ditegakkan hujjah atas orang per orang, kemudian dia meninggal di atas keyakinannya maka tidak diperbolehkan untuk mensholatkan jenazah orang tersebut yang telah tegak hujjah atasnya dan tidak ada lagi syubhatsyubhat yang ada padanya. Berarti orang yang belum tegak hujah atasnya tetap kita katakan sebagai seorang muslim dan kita harus memenuhi segala hak-haknya sebagai seorang muslim seperti mensholatkannya, mengkuburkannya dan selainnnya.

Berdasarkan dalil dan keterangan di atas, maka sikap untuk tidak mensholatkan penista agama dan pemilih orang kafir menjadi pemimpin adalah sikap yang tidak benar karena menyelisihi ketetapan para ulama dalam masalah ini. Sikap ini juga salah karena boleh jadi pemilih orang kafir menjadi pemimpin dan pendukung penista agama tersebut sebelum meninggal dunia dia bertaubat dan memperbaiki dirinya sehingga menjadi muslim yang baik. Jadi apa ada alasan untuk tidak mensholatkannya tatkala ia sudah bertaubat?!.

Oleh karena itu janganlah kita terburu-buru mengkafirkan seorang muslim atau memvonis dengan mengatakan bahwa tidak boleh mensholatkan jenazah pendukung penista agama dan pemilih orang kafir menjad pemimpin. Allahu a'lam bish showab.

\section{PENUTUP}

1. Harus dibedakan menjatuhkan vonis kafir secara mutlak (umum) dan menjatuhkan vonis kafir seseorang (individu tertentu).
2. Seorang muslim bisa divonis kafir yaitu keluar dari Islam setelah terpenuhi syarat-syarat pengkafiran atasnya sebagaimana yang telah dijelaskan.

3. Tidak diperbolehkan ummat Islam memilih non muslim menjadi pemimpin seperti gubernur.

4. Jika telah ditegakkan hujjah bagi masing-masing penista agama dan pemilih orang kafir menjadi pemimpin dan tidak ada lagi syubhat-syubhatnya maka diperbolehkan menghukum dia kafir keluar dari Islam yang berakibat orang tersebut tidak diperbolehkan untuk disholatkan jenazahnya dan gugurlah hakhaknya sebagai muslim. Namun jika belum ditegakkan hujjah atasnya dan belum terpenuhi syarat-syarat pengkafiran dan masih ada penghalangpenghalangnya, maka tidak boleh memvonisnya kafir dan kita berkewajiban untuk tetap mensholatkan jenazahnya dan memenuhi hak-hak mereka sebagai muslim. Dan yang berhak memvonis kafir seorang muslim adalah para ulama atau perkaranya dikembalikan kepada para ulama, bukan setiap orang berhak memvonis kafir seorang muslim. Dan kami memandang bahwa ummat Islam yang memilih orang kafir menjadi pemimpin, maka itu adalah perbuatan dosa besar dan diharamkan, namun belum terjatuh kepada kekafiran yang menyebabkann pelakunya keluar dari Islam, karena setia dan cinta kepada orang kafir termasuk memilihnya sebagai pemimpin itu adalah bukan termasuk perbuatan kafir selama tidak membantu mereka untuk menyakiti, 
mengganggu atau memerangi kaum muslimin; dan atau membantu mereka karena adanya kepentingan pribadi, rasa takut atau adanya permusuhan yang bersifat keduniawian antara dia dengan kaum muslimin .

\section{DAFTAR PUSTAKA}

Al-Qur'anul Karim dan Terjemahnya.

Al-Jibrin, Prof. Dr. Abdullah bin Abdul 'Aziz. Dhowabith Takfir Mu'ayyan. Cet. 2. Riyadh: Fahrasat Maktabah al-Malik Fahad al-Wathoniyyah: 1425 .

Lajnah Daimah, Fatawa al-Lajnah al-Daimah Lil Bubuts al-Ilmiyyah wal Iftaa. Riyadh: Muassasah al-Amirah alAnud Binti Abdul Aziz Alu Saud al-Khairiyyah: 1431

Ibnu Taimiyyah, Syaikhul Islam Ahmad, Majmu' Fatawa Syaikbul Islam Ibnu Taimiyyah, Syaikhul Islam Ahmad. Riyadh: Mujamma' Malik Fahad, 1416 .

Al-Utsaimin, Syaikh Muhammad bin Sholih. Majmu' Fatawa wa Rasaail. Riyadh: Darul Wathan, 1413.

Sabiq, al-Sayyid, Fiqhus Sunnah. t.t. Dar alTsaqafah al-Islamiyah, t.th.

Al-Fauzan, Syaikh Sholih bin Fauzan, AlMulakbkhash al-Fiqhi. Riyadh: Dar al-Ashimah, 1423.

Al-Fauzan, Syaikh Sholih bin Fauzan, Silsilah Syarbu al-Rasaail. Cet. 1. Riyadh: Dar al-Ma'tsur, 1436.

Al-Hilaliy, Salim bin 'Ted, Limaadzaa Ikhtartu al-Manhaj al-Salafiy?. Cet.
1. t.t. Markaz Diraasat alManhajiyyah al-Salafiyyah, 1420.

Al-Utsaimin, Syaikh Muhammad bin Sholih, Al-Qaulul Mufid Syarbu Kitab at-Taubid. Cet. 3. Riyadh: Dar Ibnul Jauzi, 1419.

Al-Najdiy, Abdur Rahman bin Muhammad (Muhaqqiq), ad-Durar al-Saniyyah Fii Ajwibati al-Najdiyah, Cet. 10. T.t. t.p., 1312.

Al-Asqalani, Imam Ahmad bin Ali Ibn Hajar, Fathul Bari Syarbu Shobih alBukhari. Kairo: Maktabah alShofa, 1424.

Al-Mawardi, Ali Bin Muhammad, alAbkam al-Sulthaniyah wal Wilayat alDiniyyah. Kuwait: Maktabah Dar Ibni Qutaibah, 1409.

Al-Jazaairiy, Abu Bakr, Aysarut Tafasir. .Kairo: Dar al-'Alamiyah, 1434.

Al-Fauzan, Syaikh Sholih bin Fauzan, alWala wal Bara Fi al-Islam. Riyadh: Dar al-Wathan, 1412.

Al-Jauziy, Syamsuddin Muhammad bin Abi Abu Bakar bin al-Qayyim, Abkam Abli adz-Drimmah. Dammam: Ramadiy Lin Nasyr, 1418. 